\section{Lone Mogensen}

Blidvädersvägen $6 \mathrm{G}$ S-222 28 Lund

SWEDEN

mogensenlone@hotmail.com

Keywords: Church, basilica, narthex, atrium, royal mansion,

Scania, Denmark, Sweden, Medieval architecture, Euclidean geometry, ad quadratum,

modules, measuring systems, descriptive geometry, symbolism

\section{Research}

\section{Making a Difference}

Abstract. In attempting to identify how the ground plans of medieval churches were initially staked out, it has been noted that the width of a given element (an aisle or a pier) equals the difference between two given distances in a square appearing in that same church; in a church plan constructed on a square module with the side 1 and the diagonal $\sqrt{2}$, several distances in that plan would be produced, such as $\sqrt{2}$ 1 and $1-\sqrt{ } 2 / 2$, a fact that is rather well known. However, the difference between those two measurements has been used. How did the original constructor actually create that difference of differences onsite? The answer was found thanks to a plan of the Dalby church (ca. 1060) and a little cord which simply needed to be folded.

\title{
The folded cord
}

This article explains how the original constructor - the medieval master builder once could have staked out the plan of a church on the ground. Of course it remains hypothetical even if it is sometimes expressed as a fact to give the explanation below a better flow.

In attempting to identify how the plans of medieval churches were initially staked out, I have found that the width, for instance of an aisle or a pier, equals the difference between two given distances in a square appearing in that same church. Take for instance a church plan constructed on a square module with the side 1 and the diagonal $\sqrt{2}$ : several distances in that plan would be produced, such as $\sqrt{2}-1$ and $1-\sqrt{2} / 2$. This is rather well known. But I also discovered that the difference between those two measurements has been used. That special distance I call $x$ here .

How did the original constructor actually create that difference of differences onsite?

Simply by examining a church plan I was not able to find an easy method to produce the distance $x$. In order to improve my chances at understanding how the constructor had created this distance I used a plan of the Dalby church, which dates from around 1060 , to scale 1:50. When I used a little cord made to the same scale as the church plan and tried to stake out the plan, the answer immediately revealed itself: the cord needed simply to be folded.

\section{History}

Today Dalby is a little village located in Scania in what is now the southernmost region in Sweden, but during the middle ages Scania was a part of Denmark. Around 1060, the Danish King Sven Estridsen was, as one medieval text put it, "the first to build Dalby church". There is a general consensus among the Dalby researchers that his church is the one in question. Some generations later, the Anglo-Saxon Benedictine monk Aelnoth mentions the Dalby site again, though not as a church but as "the famous place". ${ }^{2}$ 
King Sven continued his predessors' missionairy work in Denmark, and he installed Bishop Egino in Dalby. Egino probably had no bishopry of his own, since the dioscese of Scania belonged to the Cathedral ten kilometers away in Lund. The German Archbishop Adam of Bremen described him as a learned man and a successful missionairy bishop in Sweden and Denmark [Adam of Bremen 2000: 205]. Egino could have been the King's chancellor as well. In 1066 the Bishop in Lund died and Egino took his place. Upon his departure from Dalby he founded a college of canons which shortly after established an Augustinian monastery. Nevertheless, the Danish king kept his formal patrimony over the place, which grew to be very prestigious, independent, and wealthy.

King Sven's original basilica at Dalby was soon elongated eastwards, and a westwork, with two towers flanking a square middle part, built, although the towers were probably never completed. A lot of building activity took place on the site during the medieval ages, in part due to the growing prosperity of the monastery, but also as a result of devastating fires and war.

After the Reformation the site was impoverished by the King's favorite men whom he installed there to govern the famous place. The decay escalated when the region became Swedish in the seventeenth century. Today the choir, both the original as well as the elongated, and the eastern bay of the nave are gone, and so is the complete northern aisle. Of the twelfth century's westwork the two flanking towers are long gone. Only the bottom and part of the second floor remain of its middle part. It carries today the remnants of a later tower (fig. 1).

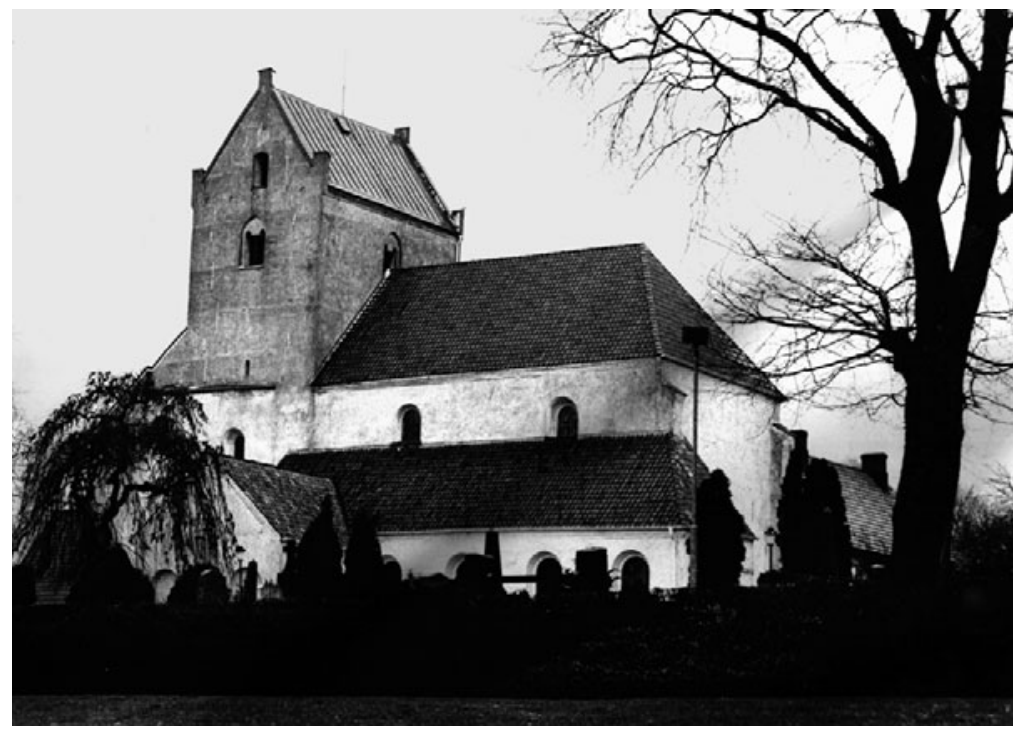

Fig. 1. The Dalby church. Photo by Knut Andreassen

During the twentieth century several archaeological excavations took place both inside and outside the church. The ground plan of the original basilica was documented, and the southwest corner of an older and original western part was found; it had most likely been a narthex. ${ }^{3}$ The really big surprise was found in the area west of the church: just under the ground surface the foundations and lower courses of two houses were discovered. These have, for good reason, been interpretated as a royal mansion consisting of a main house flanked by a southern wing. 


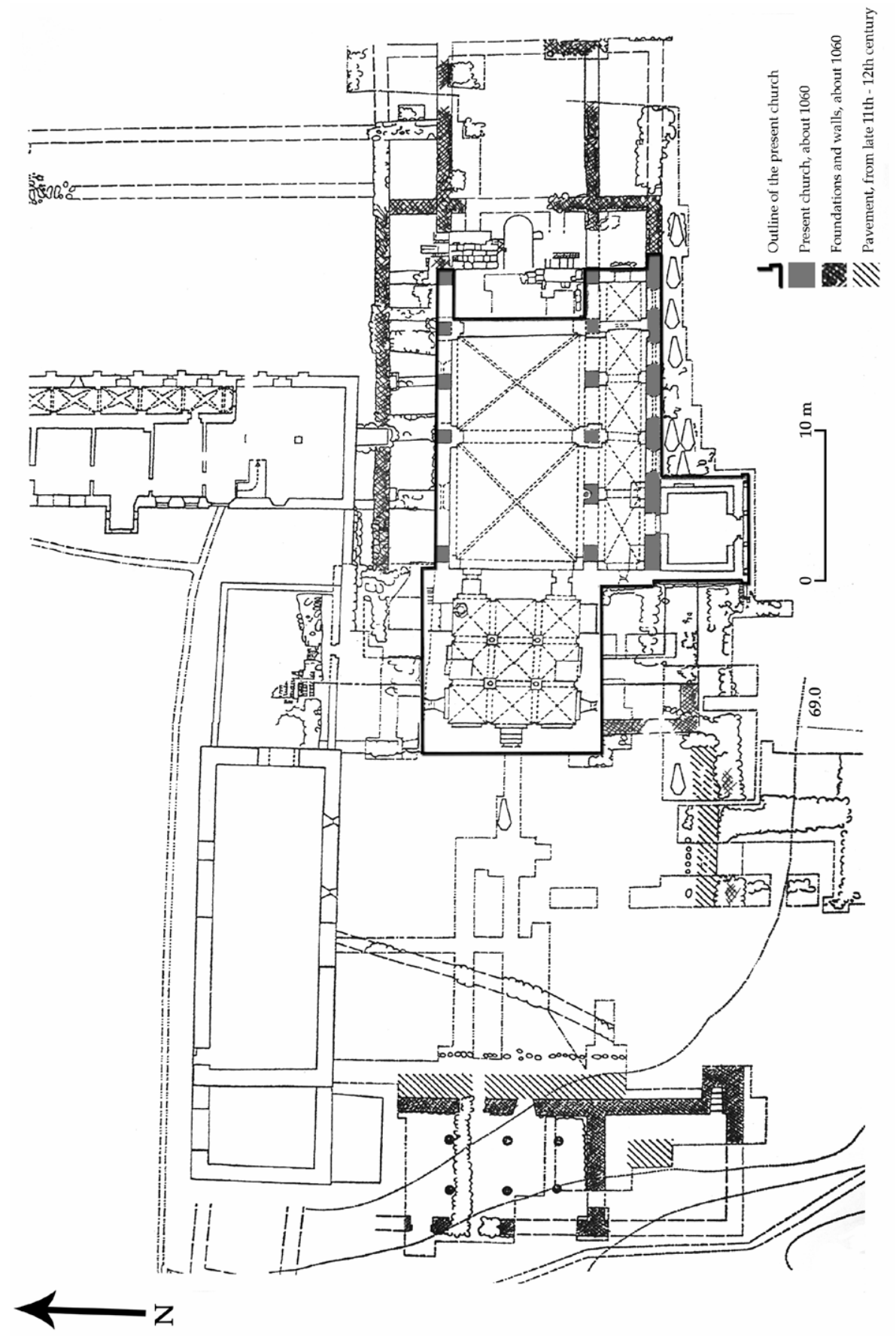

Fig. 2. The Dalby church ground plan 
The main house, which had a cellar, lay parallel to the narthex, and was more or less connected to it by the southern wing. A probable northern wing could not be identified, because that place is occupied by a complicated house with medieval origin. If a northern wing had originally been built there, the three two-storey houses would have, together with the narthex, formed an atrium (fig. 2). Nothing like this has been found in Scandinavia so far. No wonder it was called "the famous place."

\section{Staking out the plan}

On a special day in the middle of the eleventh century the orientation of the basilica would have been laid out. The location as well as the planned construction work would have been blessed in a ceremony. When the roads and bridges to the quarry nearby were reinforced, the well and the water pipe functioning, timber, iron, lime and food could be supplied; when the lodge, the craftsmen and workers were ready, the site cleared and levelled, the very erection of the walls could begin.

Prior to that, however, the plan would first need to become visible on the ground. On the site itself or in his home the master builder (whoever he was) has constructed a square module. He would have used thin ropes, perhaps made of waxed hemp. The side of the square equals 1 (in Dalby this is equal to 25,6 meters; more about this below). The diagonals are $\sqrt{2}$. He then selects one of the diagonals as a ruler, this will be - itself or the model for - a special cord that resists extension caused by either its own weight, or by water and wind. On this diagonal cord he marks out the three distances $1 / 2, \sqrt{2} / 2$ and 1 . He could have used knots as marks, but to be more precise it would be better to sew threads of different colors or metals to the rope. Here, I shall refer to these marks as "knots".

When he marks the distance 1 on the diagonal cord, this mark will divide the second half of the diagonal in two pieces: $y=(\sqrt{ } 2-1)$ and $z=(1-\sqrt{2} / 2)$. Then, using the cord alone out of the geometrical context, i.e., outside this square, when he folds it at point B (the distance 1 on the square between $y$ and $z$ ), the end of the rope will at once mark the difference between $y$ and $z$, which is the distance $x$. In other words: $x=(\sqrt{ } 2-1)-(1-\sqrt{ } 2 / 2)$. Of course all these distances can be found by a series of inscribed squares, but this is a handier shortcut (see fig. 3 ).

In Dalby the cord would probably have been at least $\sqrt{3}$ long, but here in these figures I take it to be $\sqrt{ } 2$, for simplification. This cord can also construct right angles. When using the distance $(x+z)$ as a base line fixed with pegs, and turning the cord ends up to meet, an isoceles triangle with a right angle at B is made. ${ }^{4}$ Along with the cord, the master builder would also have had a couple of rulers. It would be most convenient to use a ruler of 2.56 meters and its fractions, along with a ruler with the applied yard and foot, and their divisons.

By use of the distances between the knots of this cord, a plan designed in this way would turn out to be identical with the Dalby buildings. The module 1 is 25.6 meters, $\sqrt{ } 2$ equals 36.2 meters, and $\sqrt{ } 3=44.34$ meters. The distance $x(=3 / \sqrt{ } 2-2)$ is therefore 3.1 meters. This distance is the exact width of the still existing south aisle, measured near the floor, close to the original ground surface where the staking out threads would have run. The nave together with its two framing arcade walls are 10.6 meters, which equals the distance $y(=\sqrt{ } 2-1)$. Discrepancies are generally $\pm 0.5 \mathrm{~cm}$ or less. The excavation survey made to scale 1:50 shows a perfect match: the outlines of the walls follow the lines of this reconstruction. There is one irregularity, though, to which I shall return later. As the figures show, the staking out also includes the two buildings west of the church. 

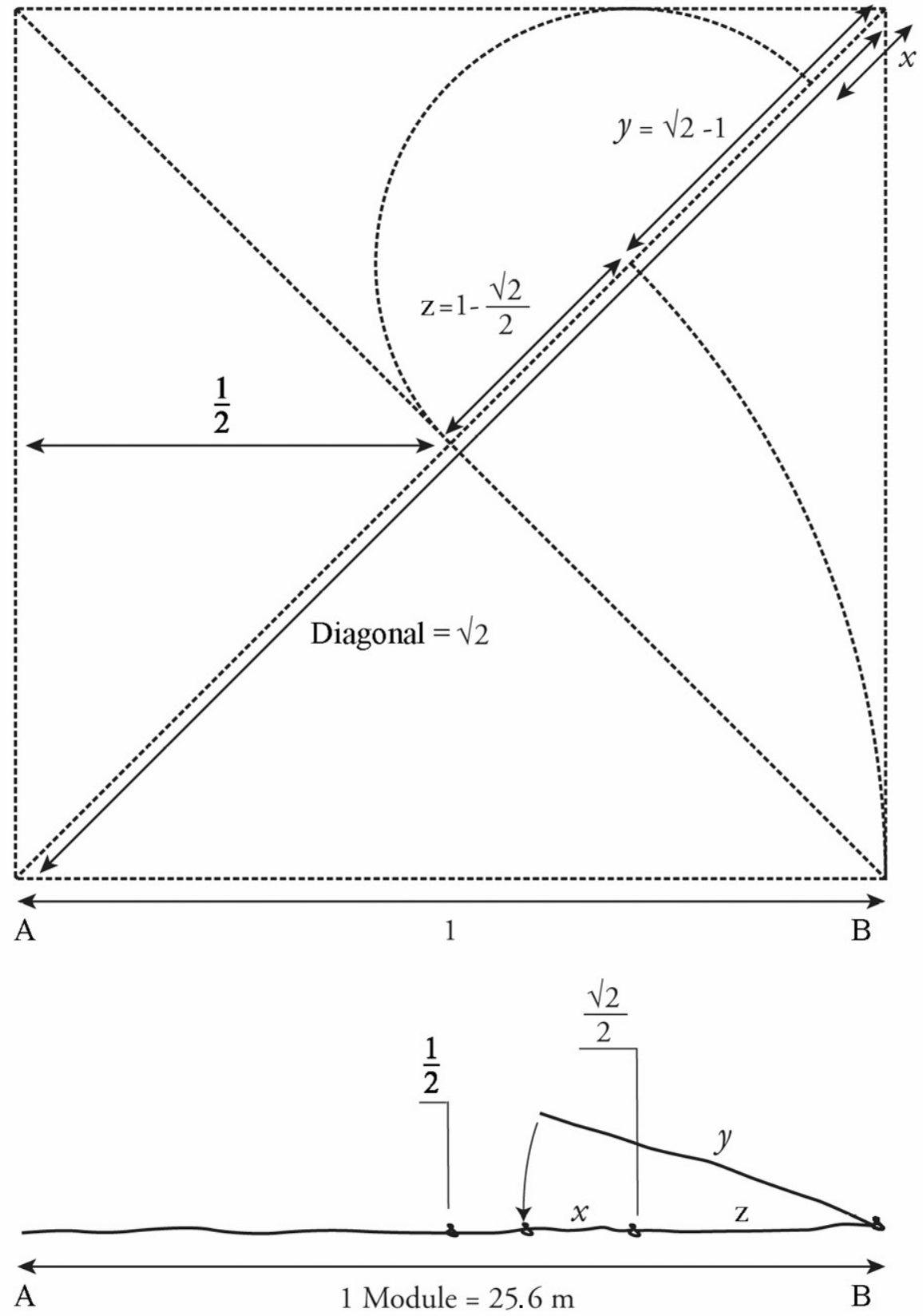

Fig. 3. 


\section{The module}

Fifteen years ago I studied the plan of Lund Cathedral as well as the building itself [Mogensen 2003]. I found a module of 25.6 meters, even if some corners of the northern nave and transept are oblique. That module is the width of the nave, between the aisle's doors, and the longitudinal distance in the crypt. The width of the crypt is $\sqrt{2} \times 25.6$ meters and the length of the nave is $\sqrt{3} \times 25.6$ meters. The differences between differences are found in the width of pillars, walls and wall segments, which all can be derived from the square module shown here and a series of inscribed squares, or simply a folded cord.

In the medieval plan of Lund I find a structure with a module of 256 meters. ${ }^{5}$ This is based on a modern map made to scale 1:1000, combined with maps of the reconstructed medieval street system, which is generally still in existence. ${ }^{6}$ Also, a very early stone church in Lund, Drotten, seems to be related to the distance 25.6 meters. The first streets, blocks and churches were laid out in the period between $990-1020$ when the Kings Harold Bluetooth, Sven Forkbeard, Hardecnut and Cnut the Great ruled. Chronologically, the city plan is oldest, followed by Drotten, the Dalby setting and then the present Lund cathedral, which is mainly from the beginning of the twelfth century. So far, I haven't found this module of 25.6 meters in other places, except in a publication about the church Østermarie on the island of Bornholm close to Scania, written by Erling Haagensen [1993: 159].

Haagensen has highlighted that this distance corresponds with several ancient measuring systems, among them an English mile: a circle with a radius of 256 meters will have a perimeter of an English mile. In fact, the radius must be a little longer, i.e., 256.032 meters, to give an exact mile. However, when I started my study I knew nothing about any given distance at all, and I did not recognize less than half a centimeter, so I stuck with 25.6 meters. Now knowing about the extra 0.32 centimeters, I still find them without importance in this context. ${ }^{7}$

It is tempting to look at plans published in books and on the Internet in order to discover this module in other buildings, ancient as well as medieval. However, in order to be sure, one has to take measurements onsite to be able to compare them with reliable drawings made to a large scale. I would therefore be very thankful if anyone else has identified this module in other contexts. The Danish architecture professor Mogens Koch has shown how the cubit, or rather the ell, used in the Lund Cathedral is the "natural cubit" of $46.666 \ldots$ centimeters, with a foot of $31.111 \ldots$ centimeters. ${ }^{8}$ Most likely the same ell was used in Dalby, because the total length of the church was either 99 or 100 such ells, depending on whether or not there was a forepart on the narthex. At least in Lund and Dalby the natural cubit seems to be combined with the module 25.6 meters. Despite these commonalities no general measurement has been identified with certainty in buildings from that period in Scandinavia.

However, whatever the module was, I did find evidence that points to the existence of a folded cord with the differences mentioned above.

\section{Mistakes and humble gestures}

There is sometimes a tendency to explain irregularities in church construction as the result of humble gestures by building masters. According to this explanation, the master mason deliberately made an "error" to demonstrate that nobody except the architect of 
the cosmos, God himself, is able to create a perfect construction. Even if the church symbolized the cosmos and the act of building a church was a humble imitation of God's great act of creation (hence the profound symbolism in the building process), there was however a blasphemous contradiction in such a gesture: if the mason did not choose to make his work imperfect, he would in fact equal the Creator in designing perfection. Furthermore, to construct a defect and integrate all its consequences in an otherwise perfect system - that requires even more skill. Maybe there was a gestus humilitatis that was sophisticated in its mere simplicity?

Most plans suffer from some imperfection which could have forced the masons to adjust both small details and the orientation of big walls. Here I present two sorts of failures which can be traced to a specific step in the setting out process, a step that the master could choose to take, or that he might easily do as a genuine mistake.

In the Dalby plan, a perfect way to stake out the width of the total nave is to use the distance $\sqrt{2} / 2$, as the second step of fig. 4 . That has apparently happened in the northeast corner. Here the total bredth of the building from point $\mathrm{B}$ to $\mathrm{C}$ appears to be 18.10 meters which equals $\sqrt{ } 2 / 2$ distance. But using that method to determine the north wall in its whole length would completely destroy the symmetry of the whole. So, to make it work, the northern wall now deviates from that corner (B) and points inwards as it extends towards west, narrowing off the distance at the western side by at least 35 centimeters.' This deviation mainly affects the width of the northern aisle and its northern wall, and hardly anything on the nave arcade.

If the mason deliberately made this irregularity, it might express something like this: "Look, how gracefully it could have been done! But alas, only the migthy Creator is able to master such an elegant simplicity in His methods. I have to do it in a more longwinded way, by adding distance to distance....".

Another sort of irregularity is the switching side of a wall. It can be seen in the plan of Lund Cathedral as well as in many other churches, among them the southern transept wall in St. Etienne in Nevers, which has previously been described in this journal [Zenner 2002]. ${ }^{10}$ Imagine the latter building site filled with stakes, between which a certain amount of strings are drawn to show the workers where to dig the foundation pits. Even if only one of the two outlines of the walls were drawn at once, the building site would have looked like a spider's web at such a stage. If, for instance, the inside of the western wall of the northern transept was important in the staking out process, a string must have been extended there, and might have continued over the middle crossing to show the corresponding outline of the southern transept. When the width of this wall was to be depicted with a parallel thread, how easy would it be to pick the wrong side of the first string?

The consequences of such a mistake, deliberate or not, can be seen as an oblique angle in a couple of corners, and a mysterious deficiency or excess of distance, emerging everywhere.

I believe that after having staked out the main structure of a church plan, the remainder was laid with either a measuring rod, such as the stick of 2.56 meters I guess was used in Dalby, which also is the space between the eastern arcade pillars, or without any tools at all, and only done by the eye. The Dalby basilica had a simple design, and the walls in the present church are still extremely straight so both sides of the walls might very well have been laid out at the same time. 
Fig. 4. Staking out the Dalby church in 10 steps. Note: the cord must be at least $\sqrt{ } 3$ long

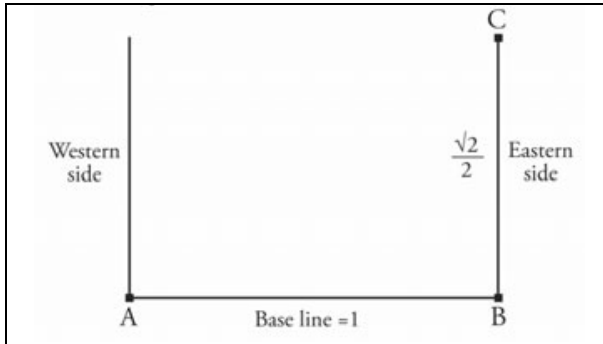

Step 1. The base line $A B=1$ is staked out. It corresponds to the inside of the south wall of the south aisle. By using the cord to make a square, the eastern and western sides are staked out perpendicular to $\mathrm{AB}$ and northwards to the distance of $\sqrt{ } 2 / 2$. The end at the eastern side is marked with a plug $\mathrm{C}$.

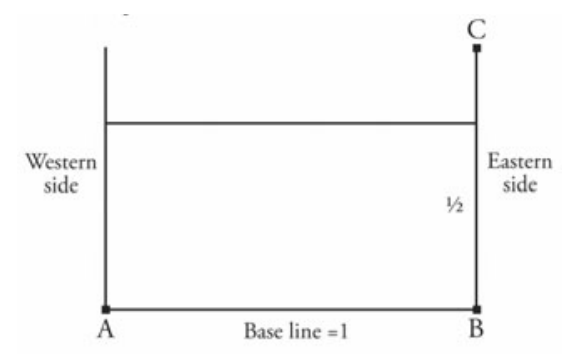

Step 2. Along the two sides the distance $1 / 2$ is marked out and a string parallel to $A B$ is drawn. This will be the inside of the northern arcade of the nave (which is the present northern wall of the church to day)

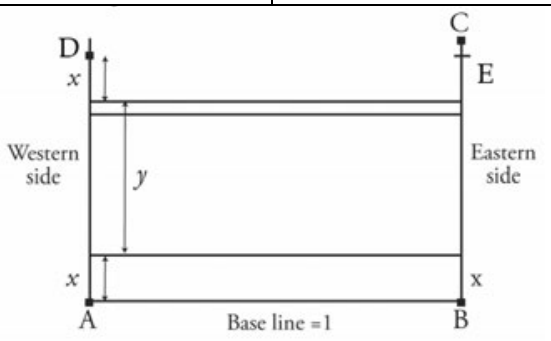

Step 3. Along the two sides the distances $\mathrm{x}$ and $\mathrm{y}$ are marked out and connected by lines parallell to $A B$. Thereafter the distance $x$ is added again on top of the $y$-distance on both sides.

The end point of the top $\mathrm{x}$ on the western side is point $\mathrm{D}$, and on the eastern side it is point $\mathrm{E}$.

The two lines limiting the $y$-distance designate the outer outlines of the arcade walls. The width of the northern arcade wall has now been produced. This width goes for all the walls and is called "the width of the wall" in this text.

The $\mathrm{x}$-distance equals the inner width of the south aisle.

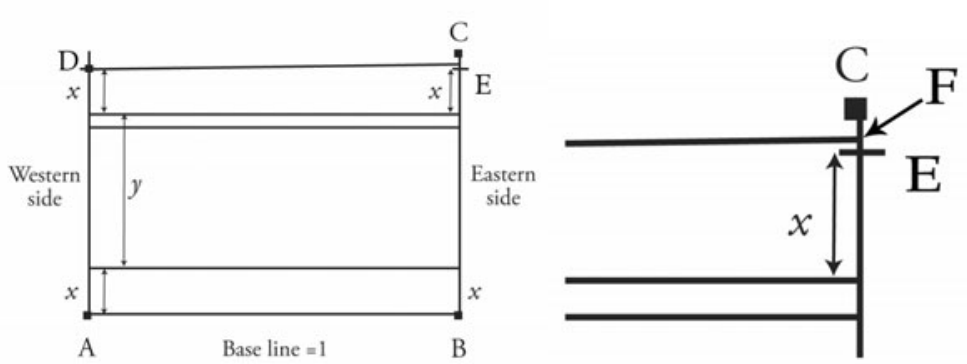

Step 4. The irregularity at the north east corner: The width of the wall is added from $\mathrm{C}$ and downwards the eastern side to point $\mathrm{F}$, just above point $\mathrm{E}$. From $\mathrm{F}$ a line is connected to point $\mathrm{D}$ on the western side, producing the interior outline of the northern wall of the north aisle. 


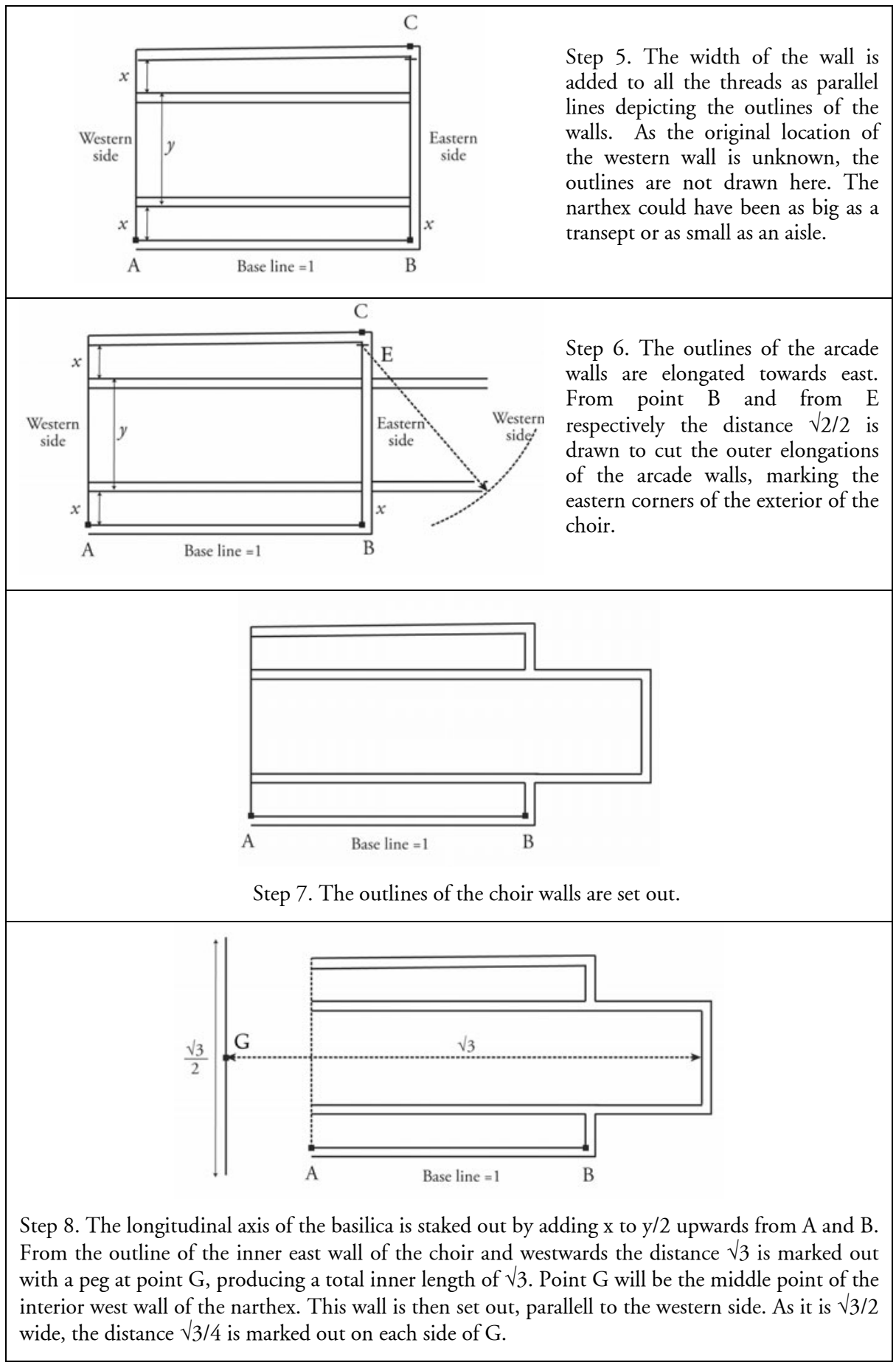



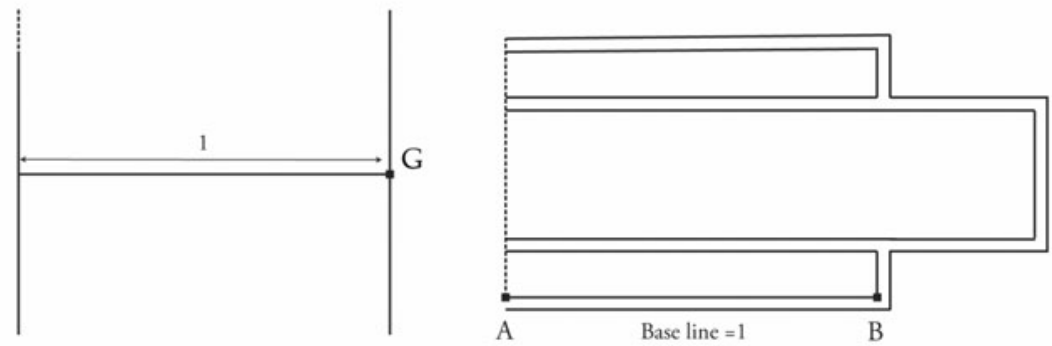

Step 9. From point $\mathrm{G}$ the distance 1 is set out westwards along the elongated axis. The distance corresponds to the atrium plus the width of the adjacent walls of the narthex and the royal mansion.

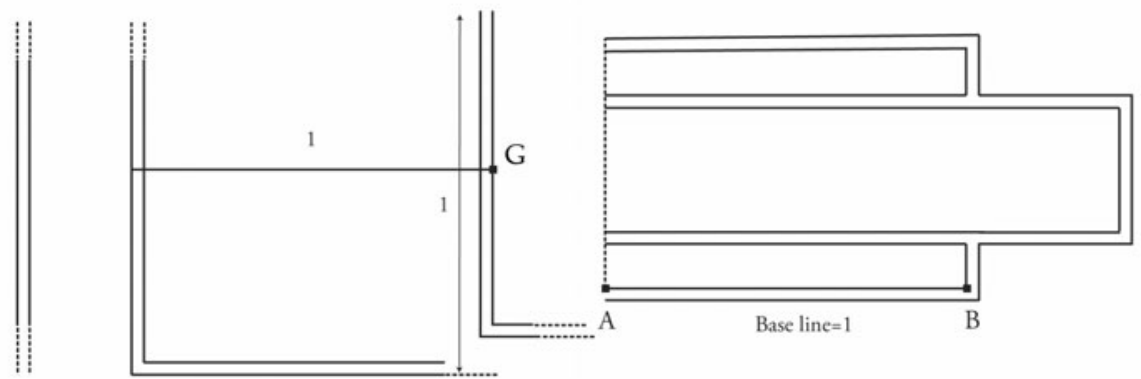

Step 10. From the north end of the narthex and southwards the distance 1 is staked out. This will be the distance to the extension of the outline of the south wing (the inside of the north wall).

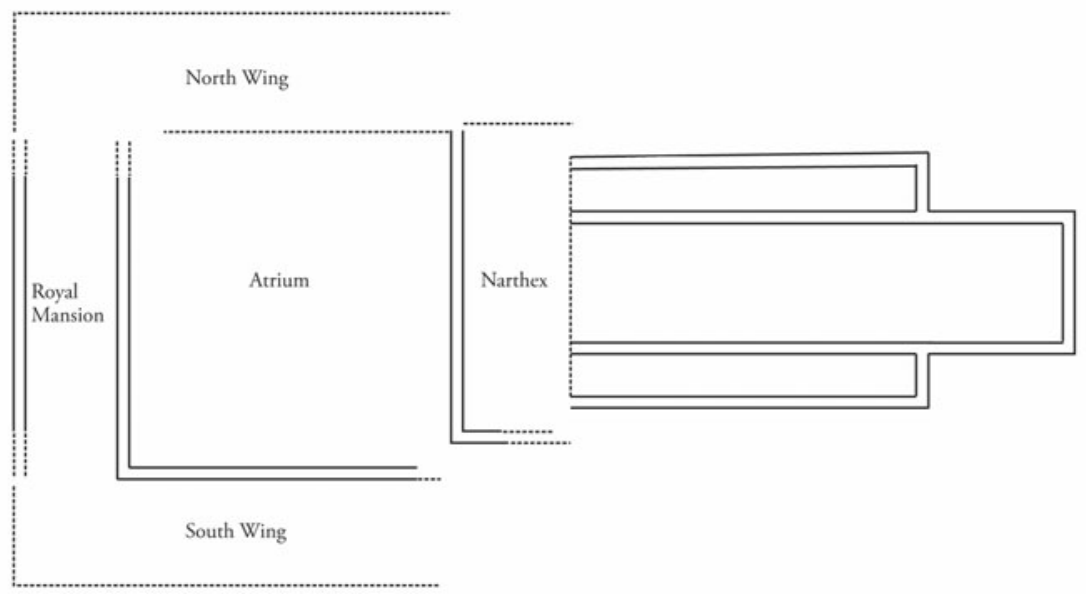

Step 11. The inner width of the mansion is $3 \times 2,56$ meters minus the width of the outer wall. A measuring rod of $1 / 10$ of the module $=2,56$ meters might have been used for staking out that distance. The inner width of the southern wing is uncertain, but it is most probably the same. The total length of the mansion could not be excavated, but it was estimated to be "about 26 meters". If a northern wing was erected, it was probably placed where a medieval house still stands today. 


\section{The Cord}

The cord as a tool in the staking-out process can be traced considerably far back in time. At Abydos there is an inscription that tells of the sacred moment when the Egyptian Pharaoh is "stretching the cord" at the commencement of the construction of a new temple: with the help of the circumpolar stars and a water clock the Pharaoh first determined the orientation of the temple [Schneider 2002]. Then, together with Sechat, the mistress of divine books, the Pharaoh laid out the sides of the planned temple with a cord stretched between stakes. They "determine its four angles by striking the stakes with a golden mallet" [de Lubicz 1985: 94-95]. This divine act is not quite comprehensible, but perhaps it is reflected today by carpenters producing straight lines: a chalked string is held taut and then abruptly released to reveal a straight line to guide construction. When Pharaoh struck the stakes, the vibrating cord would produce an imprint on the ground. A similar technique could have been employed at the outset of the buildings in Dalby (how to determine the four angles is described by Peter Schneider [2002]).

The use of a cord as a measuring device is also mentioned in the Old Testament in Ezekiel's vision when a man, "whose appearance was like the appearance of brass" (Ezekiel 40: 3), uses a measuring cord to enlighten the prophet as to the exact measurements of the next temple (which are explained in detail in Ezekiel 40-47). The cord is actually mentioned even further back in time: when the Sumerian godess Inanna is drinking wine with $\mathrm{Ea}$, she is presented with the seven pairs of me. The me is like the Egyptian Ma'at, the universal measures or rules for correct behavior, whether you are a star, a planet, a plant or a human being. The first me Inanna is given is "the stick and the cord". When she later descends to the netherworld she must let go of the seven me again, the last of which is the stick and the cord.

As Inanna was regarded as the Queen of Heaven, I can only interpret the items in her hands as measuring tools: they are rulers for creating the world and everything in it, and for how all these things shall move and relate to each other. The cosmic woman with the cord is also recognized as the mythical spider woman, known in the Americas as well as in Greece, and as the spinning goddess of fate, seated at the celestial pole - North or South - turning her spindle and thus making the heavens revolve. Isis and Ishtar were both depicted with spindles in their hands, and they were called "Queen of Heaven" which obviously was a function and not an empty title. It corresponds to the fact that a former pole star was called the Spinning Maiden in China and Japan [Olcott 1936: 261]. ${ }^{11}$ In a Scandinavian myth, when the hero Helge is born, a valkyrie casts out her cosmic thread into the sky to stake out the time and space of his reign. Maybe the old measures for yarn and skeins have something to tell us about measuring? In Sweden they express the ancient duodecimal system with parallels to geometry and astronomy, evidenced by the fact that numbers such as 1080 are frequently used. ${ }^{12}$

Perhaps it is worth looking closely at the fragments of prehistoric threads, yarn and rope previously found by archaeologists. Very often these finds are interpretated as parts of a "net" for fishing or hunting. I think that such nets were also intended for carrying food, luggage and children, but is it not also possible that some of these items might in fact have originally been measuring tools? An example of such a revised interpretation has recently been given in Denmark. Dancer Anni Brøgger borrowed all the bronze age "Egtved girl's" reconstructed equipment from the Danish National Museum for an experiment. She wore the string skirt, the blouse and the adornments every day in the summer while doing basic chores (gathering herbs, cooking, taking care of children), and demonstrated that the string skirt was extremely unpractical for any activity other than 
dancing [Brögger 2003: 21]. ${ }^{13}$ Besides, she realized that a long wollen thread with knots which persistently had been assumed to be a "hair net" was in fact a measuring device for making the skirt. ${ }^{14}$ The distance between the knots directly correspond to the length of the strings and to the adjustments on the belt. The knotted thread, then, could very well have been a "recipe" for producing the skirt.

This is the same function the hypothetical cord in Dalby would have served. It was a recipe, a geometric formula, for constructing the plan. It was probably produced for this task alone and required no marks for any other units such as yards, cubits or feet.

Such a cord formula of a basilica-to-be would have been precious. Without it, the master was not able to "raise the building from the ground" which perhaps could be a new interpretation of the "Uszuge us dem Grunde zu nemen", as is said in the late medieval Regensburg ordinates. ${ }^{15}$ How to do this should be kept secret. Until now, I did not understand the neccessity of keeping the builder's knowledge secret. The specialization of carpentery, of ashlar dressing and of designing demanded so many years of practice that it seems hard to imagine pirate copying by laypersons anyway. But if such a formula of knotted cord really existed, it would wisely have been kept very safe, possibly even secret.

Perhaps that is why we know so little about it.

\section{Acknowledgments}

The staking out system with the folded cord was first described briefly in "Den berömda platsen" [Mogensen 2010]. Thanks to Rheem Al-Adhami and Petter Lönegård for the illustrations. Special thanks to Rheem Al-Adhami for editing the text and assistance with translating concepts, to Erik Cinthio for important tips, and to Niels Bandholm for checking the geometry.

\section{Notes}

1. Ipse primus dalbyensem ecclesiam edificavit, in "Memoriale fratrum" [Weibull 1923: 69].

2. One of King Sven's five sons, all of whom became Danish Kings, was buried at "locus celebris, qui Dalby, id est Vallis villa, lingua Danica dicitur", according to Aelnoth, Life of St. Canute the Martyr, written in 1109; see [Cinthio 2006: 32, 88].

3. The corner of an original western part (probably of a narthex) has been overlooked by most researchers. It was however mentioned by Sten Anjou [1930: 30-31], who was in charge of the first modern excavation around 1920. It was later well documented and described by Karin Andersson in her Archaeological report to Riksantikvarieämbetet, Lunds universitets historiska museum (1970: 24).

4. This was discovered by Niels Bandholm, when he kindly controlled this setting out system. During this job he also identified some puzzling algebraical functions of the module 25.6. To construct a $1: \sqrt{2}$ triangle in this way is in fact an ancient method of creating a "proper square" [Schneider 2002:213-214].

5. In this structure appears the Thaleskonstruktion mentioned by Klaus Humpert and Martin Schenk [2001: 346].

6. The original setting out of the city plan of Lund has not yet been published, but it is partly depicted in [Mogensen 2003: 12 and 49].

7. The measurements published by Sten Anjou [1930] show that the width of the church walls measured close to the foundation is $0.9 \mathrm{~m}$. In the remaining building the walls tend to widen upwards to $0.95-1.0 \mathrm{~m}$. The reported width of the walls of the western house is $1.0 \mathrm{~m}$. In this staking out plan the width is $0.9 \mathrm{~m}$. The original module was probably $25.6032 \mathrm{~m}$., which would produce the width $0.90977 \mathrm{~m}$.

8. [Koch 1993: 97]. He found the same unit in Ribe Cathedral, Denmark [1993: 113], and then [1993: 115] he discusses its relation to the Greek foot: $46.666 \times \sqrt{ } 2=65.9966 \approx 66$, which is 2 
Greek feet. The diagonal of a square ashlar with the side $=0.4667$ meters is therefore 2 Greek feet.

9. This is measured from the archaeological survey where at least 2.5 meters is still lacking of the western end of the aisle. By applying the method $x+y+x$ the total distance along the western side of the square module would have been $17.7 \mathrm{~m}$., which is $40 \mathrm{~cm}$. less than BC. The original site of the western wall is not known, but was probably along that line or even further westwards.

10. See also [Nancy Wu 2002], particularly the articles by Marie-Thérèse Zenner and James Addiss.

11. For more myths about cosmic cords see [de Santillana and von Dechend 1970] and [Mogensen 1996].

12. The number 1080 is a half "age" of 2160 years, which is a twelfth of a precessional cycle of the equinoxes.

13. Curator Flemming Kaul of the National Museum has included this result of Anni Brögger's experience in his official presentation of the Egtved girl. See the video on the Internet: http://www.nationalmuseet.dk/sw59875.asp.

14. The knotted thread was not found in the dead girl's hair but in a separate little box together with an awl. The box had been placed beside her body in the oak coffin when she was buried about $1370 \mathrm{BC}$.

15. The word Grund is usually translated as "foundation". In "The Secret of the Medieval Masons," Paul Frankl presents two interesting interpretations of this quotation [Frankl 1945: 46].

\section{References}

AdAm of Bremen [Adamus Bremensis]. 2000. Adam af Bremens krønike., Allan A. Lund, trans. Århus: Wormianum.

Anjou, Sten. 1930. Heliga korsets kyrka i Dalby. Göteberg.

BRÖGGER, Anni. 2003. Egtvedpigens dans. Mammut.

CinTHIO, Erik. 2006. Minnen från Lund och Dalby. Lund: Art Factory.

FrankL, Paul. 1945. The Secret of the Medieval Masons. The Art Bulletin 27, 1: 46-60.

HaAGENSEN, Erling. 1993. Bornholms mysterium. Copenhagen: Bogans Forlag.

HUMPERT, Klaus and Martin SCHENK. 2001. Entdeckung der mittelalterischen Stadtplanung. Das Ende vom Mythos der "gewachsenen Stadt". Stuttgart: Theiss.

KoCH, Mogens. 1993. Geometri og bygningskunst. Copenhagen: Christian Ejler.

DE LubiCZ, R. A. Schwaller. 1985. The Egyptian Miracle: The Wisdom of the Temple. New York: Inner Traditions.

MogenSEN, Lone. 1996. Himlasagor och stjärnmyter. Stockholm: Alfabeta.

-2003. Kosmisk by. ärkebiskoparnas Lund. Malmö: Förlagshuset Nordens Grafiska Ab.

2010. Den berömda platsen. In Dalby kyrka. Om en plats i historien, Anita Larsson, ed. Lund: Historiska Media.

OlcotT, William Tyler. 1936. Star Lore of All Ages. New York: G. P. Putnam’s \& Sons.

DE SAnTillana, Georgio and Herta von DeChend. 1970. Hamlet's Mill. Boston: Gambit.

SCHneider, Peter. 2002. The Puzzle of the First Square in Ancient Egyptian Architecture. Pp.

207-221 in Nexus IV: Architecture and Mathematics, Kim Williams and Jose Francisco

Rodrigues, eds. Fucecchio (Florence): Kim Williams Books.

WeIBULL, Lauritz. 1923. Necrologium Lundense. Lund.

Wu, Nancy, ed. 2002. Ad Quadratum. The Practical Application of Geometry in Medieval Architecture. Aldershot, UK and Burlington VT: Ashgate.

ZENNER, Marie-Thérèse. 2002. Villard de Honnecourt and Euclidean Geometry. Nexus Network Journal 4, 2 (Autumn 2002): 65-78.

\section{About the author}

Lone Mogensen is a retired archaeologist and author. 